\section{UNIFICATION OF MULTIMEDIA WITH TECHNIQUES OF ART AND VEDIC APHORISMS FOR DEVELOPMENT OF MATHEMATICAL SKILLS: A STUDY OF INDIAN AND UK SCHOOL STUDENTS}

\section{ABSTRACT}

Multimedia programs having a number of elements like Texts, spoken words, sound \& music, graphics, animations and still pictures provide different stimuli in their presentations. Art is the field of education that provides a platform for rigorous investigation, representation, expression, and reflection of both scholastic content and the art form itself. The integration of art with other subjects of the school curriculum can open new pathways of learning for students. Vedic It is not simply a collection of new computational techniques; rather, it provides an entirely different approach to the mathematical computation based on pattern recognition. The present paper deals with the development of multimedia packages using techniques of art and Vedic aphorisms on some selected common topics of curriculum of UK and Indian elementary mathematics and the effectiveness of multimedia packages for the development of mathematical skills. The study was conducted using quasi experimental design for research in both countries. The quantitative analysis of data revealed that the multimedia packages developed by using techniques of art and Vedic Aphorisms have significantly improved the mathematical skills of UK elementary school students.

\section{KEYWORDS}

Mathematical skills, multimedia, techniques of art, Vedic aphorisms

HOW TO CITE

Bawa S. K., Kaushal R., Dhillon J. K. (2020) 'Unification of Multimedia with Techniques of Art and Vedic Aphorisms for Development of Mathematical Skills: A Study of Indian and UK School Students', Journal on Efficiency and Responsibility in Education and Science, vol. 13, no. 3, pp. 130-139. http://dx.doi.org/10.7160/eriesj.2020.130303

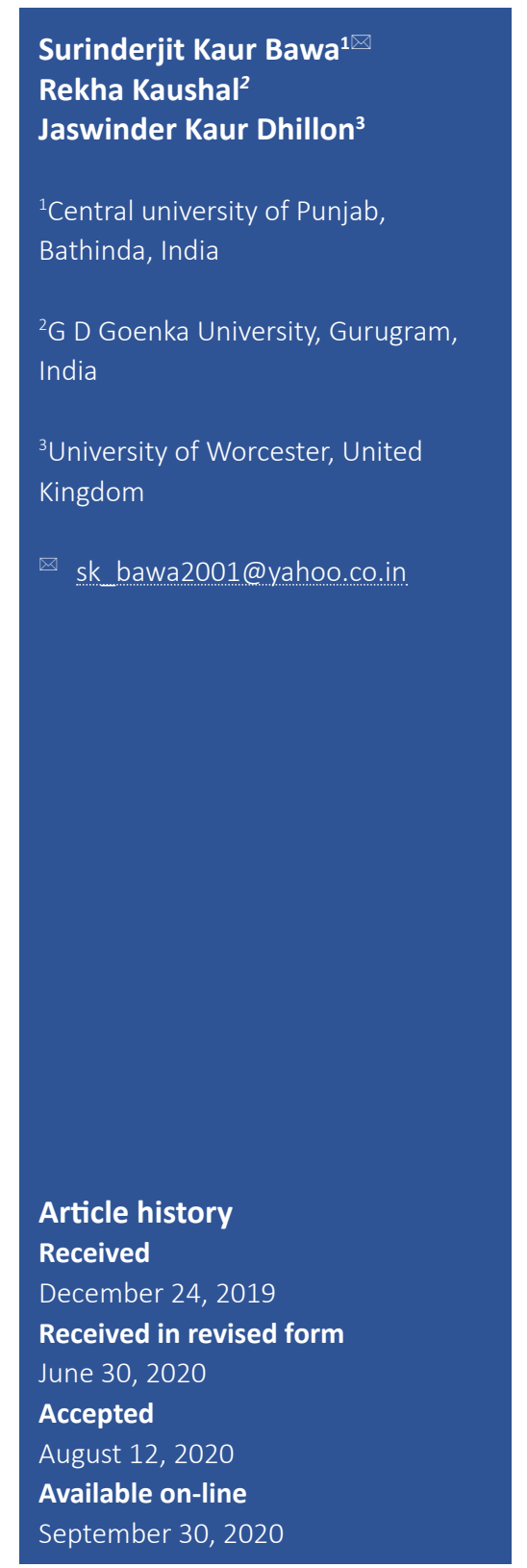

Highlights

- Development of Mathematical Skills with techniques of art and Vedic aphorisms using quasi experimental design. - Multimedia packages developed by using techniques of art and Vedic aphorisms have not been found to be effective in

- Techniques of Art when integrated with multimedia have significant effect on the development of mathematical skills of

students

\section{INTRODUCTION}

students inside as well as outside the classroom. They speak Learning through embedded multimedia proves to be superior to others in the language of technology and they are expected to the learning in verbal conditions. Lessons or instructions to do the same inside the classroom and get the best out of it. provided by multimedia technology are preferred by learners The use of multimedia in the classroom can significantly as well as instructors for better and improved classroom enhance student's achievements if systematically designed results. All the students have access to technology these days. and implemented. Students use the information provided to Computers, internet, cell phones are available all the time for them through visual and auditory presentations to construct knowledge. Experimental research studies done on multimedia as a strategy to faciliate teaching in the classrooms explored that it helps in imparting the educational material to students
effortlessly and has enhanced the trend to use technology and also showed a positive impact on development of cognitive abilities, academic success, understanding and of cognitive Learning through multimedia is always a major concern for mathematics teachers. The mats in nature. Therefore, students cannot realize the chare abstract and meanings of these symbols, and then it becomes unreasonable to ask students to recount their arithmetic calculations. As technology is
progressing continuously, teaching mathematics using different tools of multimedia is becoming a new and improved way of instruction (Malik and Aggarwal, 2012: 468). Learning is enhanced by the use of multimedia tools like visuals, sound, text and motion. Making use of these visual representations to teach mathematical skills produce positive results for the learner (Flanagan, 2002).

A newspaper article by Clark (2012) reported that there is a mathematics crisis in the UK and the universities are closing down those degree courses which require mathematical skills. The report also revealed that England is one of the few developed countries that are failing to educate their students in mathematics at elementary stage. The authors visited the elementary schools of UK, the teachers of those schools shared that students lack their interest in mathematics and many a times their total achievement gets affected by achievement in mathematics. In Indian elementary schools, the same condition was also prevailing, where the students refused to choose mathematics even at secondary level due to lack of interest in mathematics. After understanding the condition of elementary mathematics in both the countries, authors thought to develop a multimedia package to develop interest and enhance achievement of the students in mathematics using art and vedic aphorisms. The multimedia packages were developed taking into consideration whether these proved systems would be effective in India and UK having different systems of education.

\section{REVIEW OF LITERATURE}

Over the last few years, a number of researches have bee conducted to investigate the impact of using multimedia tools in learning. Multimedia is a combination of auditory verbal and visual/pictorial material presented in a systematic way (Mayer, 2012). It may include power point presentation that strengthens deeper understanding using graphics an onscreen text (Mayer and Johnson, 2008: 385), virtual games, computer assisted instructions and multimedia in combination with structured guidance and moreover, reflection technique can foster potentially deep understanding of inexperience learners (Moreno and Mayer, 2004. 172; Moreno and Mayer, 2005: 127). These multimedia strategies can be used in any content area. Presentation of verbal and visual material e.g. videos integrated with exchanges of ideas are most effective for beginners and learners who learn from visuals. That is why the lessons incorporated with effective video clips are more appropriate for slow learners and under achievers for teaching complex topics and for introductory courses. Undoubtedly al other students and subjects are benefited as well.

The research findings on the effectiveness of videos clips

ERIES Journal

volume 13 issue 3 embedded multimedia in classes are very motivating. A number f studies in the specific areas have produced significant results which favors the use of multimedia in classroom teaching Seago, 2015: 259; Wang and Hartley, 2003:105; Brophy, ( Pryor and Bitter, 2008: 2668). Stimuli presented by multimedia using auditory and visuals increases retention, promotes deeper understanding and comprehensive learning.

Vedic Mathematics is the name given to that system in which, mathematics is based on 16 sutras, which are also known as aphorisms. The whole system of Vedic mathematics is interrelated and unified because the most important feature of Vedic mathematics is coherence. This unifying quality makes mathematics easy, pleasurable and encourages uniqueness. The eachers should use sutras or aphorisms of Vedic Mathematics in mathematics class along with other methods which will definitely benefit the students to achieve better and solve the problems in short time. An example of vedic mathematics with the use of one of its aphorisms for multiplication is cited here. The name of the aphorism is 'Nikhilam Sutra' as given in this aphorism, it is done by choosing a nearest base (base will be the multiple of 10). For these two numbers ( 9 and 8 ), base will be 10 . Then, the numbers are to be subtracted from the base and write the difference beside the number with minus sign as follows. Then, multiply the right-hand side numbers vertically and write the product below. After this, cross subtract below:

$\begin{array}{r}\text { Base } 10 \\ 9-1 \\ 8-2 \\ \hline 7 / 2\end{array}$

The Nikhilam Sutra could be extremely helpful for the multiplication of bigger numbers also which are near to the base of multiples of 10 .

There is significant reduction in the time duration to solve the problems using Vedic mathematics in basic arithmetic

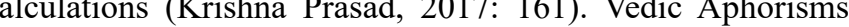
aprove the computational skills of the learners in a wide in of problems, ensuring both speed and accuracy because in istricly based on rational and logical reasoning. Vedic proved to put a positive impact on students' performance (Ismail and Sivasubramniam, 2010: 133).

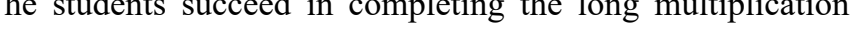
problems involving tables more than five times correctly pound that a greater number of problems have been solved by the

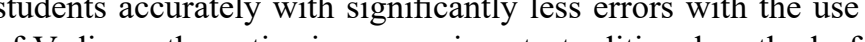
ef Vedic entic mathematics also improves the 政 (Dani, 1993: 236). The kning for competitive examinations (Dan, 193. 236). The knowledge of such methods enables the teachers to be more resourceful to mend the students and improve their talent and creativity.

1803-165N Printed ISSN 
Schools integrating the arts into the curriculum as part of comprehensive education reform strategy are documenting positive changes in the school environment and studen performance (Richard, 2002). The students who are show regularity in class and become more creative than those students who are not exposed to art activities in the school. Use of arts in the classroom as a way of teaching students opens up the pathways for their success both in the classroom and outside world that lasts for the lifetime (Melnick, Witmer and Strickland, 2011: 154). When art and other creative activities are combined with mathematics, gives learners and teachers to interact creatively and makes 2017: 13). Education of mathematics through art and lively activities is an effective way to get one's hand on between
mathematics attitudes and joy of learning and support the students in their achievements in the subject of mathematics (Fenyvesi, Koskimaa and Lavicza, 2017: 107). Creating visual illusions through playful and artistic procedures, holds an exciting pedagogical opportunity for raising students' attention towards mathematics. Mathematics is a subject that always seems to be difficult and boring for most of the students but teaching mathematics can be made
interesting and retainable in the minds of pupils using different innovative approaches. One of these approaches is teaching mathematics using techniques of art. Integrating the arts into mathematical experiences bring a creative and enjoyable quality to the learning and often makes it more comprehensible for those who are less inclined toward math. Moreover, Integration of art in teaching and learning process has turned up at frontline in response to the regular deterioration of scores of students (Harlin and Brown, 2007: 3). Artistic process means one makes, does and creates something real. Likewise, these are the most realistic experiences which are essential to learn and enjoy math. If one proceeds from the premise that artistic experiences significantly enhance learning, needless to say then, that students' understanding and appreciation for math will be deepened when it is presented to them in an artistic way. Arts become the encouraging factor of learning when it relates to the basic part of the curriculum as well as Integration of art in teaching makes students enable to effortlessly understand the subject matter, ideas and concepts by connecting discrete curricula with the arts (Fowler, 1996; Krug and CohenEvron, 2000: 285). Art brings enjoyment to the lives of those who embrace it. Moreover, the use of painting, dance,
theatre, poetry in the mathematics teaching and learning makes its more interesting.

A report by Clark (2012) explains that sub standards of mathematics education from decades had led to a crisis in number skills among students in England and due to this universities are dropping mathematics from their degree courses because the students as well as lecturers are incapable to manage their mathematical skills. The report
also claimed that complex problems of mathematics are not also claimed that complex problems of mathematics are not
easy for the students to tackle with and their teachers are also easy for the students to tackle with and their teachers are also Mathematical skills at elementary level has been recognized
struggling to teach them mathematics anyway. The reasons of work today at many places around the world. There is a significant gap between the knowledge and skills the students learn in school and the knowledge and skills workers need in workplaces and communities. Therefore, teachers need to promote conceptual understanding by using manipulatives to teach mathematical skills (Maccin and Gagnon, 2000: 2; 2006: 217). Preparation of teaching school for the development of skills in this subject because change and improvement in the context of using technology in learning environments invite participation, engage intensified by the fact that most of the teachers lack skills resistance of some teachers towards innovative and the traditional teaching and learning methods (Tramonti, 2018 skills making it an abstract subject and lack of connection of its immediate application in everyday life jeopardizing the importance of connection between scientific topics and reality (Ausubel, 1990). Amalgamation of technology way to develop the mathematical skills of the students of elementary classes. The study has been conducted to achieve the following objectives:

1. To develop mathematical skills among Indian elementary school students and elementary school students of UK using techniques of art through multimedia packages.

2. To explore the effectiveness of multimedia package developed using Vedic Aphorisms for enhancing mathematical skills of Indian elementary school students and elementary school students of UK.

3. To compare the development of mathematical skills of Indian and UK elementary school students with $\mathrm{m}$

4. To compare the development of mathematical skills of Indian and UK elementary school students with multimedia packages developed by using Vedic aphorisms.

Thus, the objectives of the present study are framed explore the effectiveness of multimedia packages developed by using techniques of art and Vedic aphorisms and to compare the development of mathematical skills of Indian and UK elementary school students with multimedia packages, the paper addressed the following hypothesis.

1. Mathematical skills of Indian elementary school
students will significantly improve with multimedia students will significantly improve with multimedia packages developed by using techniques of art and
Vedic aphorisms. will significantly improve with multimedia packages
developed by using techniques of art and Vedic developed by using techniques of art and Vedic
aphorisms. aphorisms. learning material has emerged as an important factor within of using technology effectively in their classrooms and the and their persistence in managing of their classes with 1492). This leads to the under development of the required with Vedic aphorisms and art techniques is an interesting

2. Mathematical skills of UK elementary school students

There will be no significant difference in the dian and UK developed by using techniques of art.

of of mathematical skills of Indian and UK elementary by using Vedic aphorisms.

\section{MATERIAL AND METHODS}

\section{Design and Sample}

The study was conducted using Quasi experimental design. The data comprised of 180 students of three elementary schools from UK and India each. 90 students from each country were selected. 30 students from each school of UK and India were the participants of the present study. The grade of students selected for the experiment were 6,7 and 8 in India and key Therefore, common grades were decided as 7 and 8 for the present study who are in the age group 11 to 13 years. Students were selected randomly from these school having diversity of students as far their achievement level is concerned. Common topics from the existing mathematics curriculum of both the countries applicable for the age group 11-13 years were selected. First school was taken as control group, second school as experimental group I in which techniques of Art were applied and third school was taken as experimental group India as well as UK.

\section{nstruments}

The multimedia packages using techniques of art and Vedic aphorisms on 6 selected topics of elementary mahematics which were common to Indian and UK curriculum of mathematics for elementary classes \& Mathematical Skills Test for elementary school students of India and UK were RESULTS

Effectiveness of Multimedia Package using Techniques of Art and Vedic Aphorisms for developing Mathematical Skills among students in India

To find out the effectiveness of multimedia packages using 列

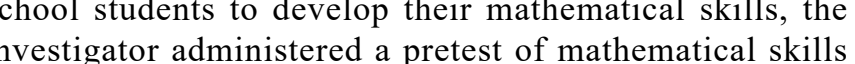
of elom ans tudents were students studying in Indian schools. The with multimedia packapes using techniques of arts and Vedic aphorisms which was then followed by a post-test of mathematical skills. Descriptive statistic for the control and experimental groups has been presented in table 1 and table 2 reveals the results of analysis of covariance. ctronic ISSN Printed ISSN 


\begin{tabular}{l|c|c|c} 
& Mean & Std. Deviation & $N$ \\
\hline Control Group (IC) & 9.43 & 2.694 & 23 \\
\hline Experimental Group with multimedia packages using techniques of art (IEA) & 9.72 & 2.851 & 25 \\
\hline Experimental Group with multimedia packages using Vedic (IEV) & 6.76 & 2.851 & 17 \\
\hline Total & 8.85 & 2.954 & 65 \\
\hline
\end{tabular}

l: Effectiveness of Multimedia Packages vis a vis Mathematical Skills (India) - Descriptive Statistics, 2019 (Source: own Calculation)

Table 1 depicts that the values of mean and standard deviation of experimental group which was taught with multimedia of control group are 9.43 and 2.694 respectively, mean and packages using Vedic aphorisms are 6.76 and 2.538. To covariate standard deviation of experimental group which was given the initial scores of Indian elementary school students on their intervention with multimedia packages using techniques of art mathematical skills, test of analysis of covariance was applied are 9.72 and 2.851 respectively and mean and standard deviation and the results of univariate test are presented in table 2.

\begin{tabular}{l|c|c|c|c|c}
\multicolumn{1}{r}{ Source of Variation } & Sum of Squares & df & Mean Square & $\boldsymbol{F}$ & Significance of $\boldsymbol{F}$ \\
\hline Covariates (pre-test) & 134.51 & 1 & 134.51 & 25.38 & $<0.001$ \\
\hline Main Effect (Treatment) & 12.40 & 2 & 6.20 & 1.17 & 0.317 \\
\hline Explained & 323.24 & 64 & 5.29 & & \\
\hline Residual & 5645.00 & 65 & & & \\
\hline Total & 558.46 & 64 & & & \\
\hline
\end{tabular}

2: Effectiveness of Multimedia Packages vis a vis Mathematical Skills for Indian Students, 2019, (Source: own calculation)

Table 2: Effectiveness of Multimedia Packages vis a vis Mathematical Skills for Indian Students, 2019, (Source: own calculation)
It is revealed from the above results that $F$ value of 'Method' Effectiveness of Multimedia Package using comes out to be 1.17 and significant value is 0.317 . It indicates Techniques of Art and Vedic Aphorisms for that significant difference does not exist in mathematical skills developing Mathematical Skills in UK of Indian elementary school students with multimedia packages developed by using techniques of art and Vedic aphorisms. The To find out the effectiveness of multimedia package hypothesis which stated that mathematical skills of Indian using techniques of art and Vedic aphorisms to develop elementary school students will significantly improve with the mathematical skills of elementary school students of multimedia packages developed by using techniques of art UK, the pretest of mathematical skills was administered and Vedic aphorisms has been rejected. Therefore, multimedia on elementary students studying in schools of UK. After packages developed by using techniques of art and Vedic the pretest, students were taught topics of elementary aphorisms have not been found to be effective for development mathematics with multimedia packages using techniques of mathematical skills of elementary school students of India. of arts and Vedic aphorisms which was then followed by It may be interpreted that multimedia packages developed a post-test of mathematical skills. Descriptive statistic for by using techniques of art and Vedic aphorisms do not have the control and experimental groups has been presented significant effect on development of mathematical skills on in table 3 and table 4 reveals the results of analysis of Indian elementary school students.

\begin{tabular}{l|r|r|r}
\multicolumn{1}{c}{ Name of the group } & Mean & Std. Deviation & N \\
\hline Control Group (UC) & 10.76 & 1.690 & 25 \\
\hline Experimental Group with multimedia packages using techniques of art (UEA) & 11.63 & 2.297 & 30 \\
\hline Experimental Group with multimedia packages using Vedic (UEV) & 9.05 & 3.031 & 22 \\
\hline Total & 10.61 & 2.566 & 77 \\
\hline
\end{tabular}

3. Effectiveness of Multimedia Packages vis a vis Mathematical Skills (UK)-Descriptive Statistics, 2019, (Source: own calculation)

Table 3 shows that the values of mean and standard deviation of experimental group II (UEV) are 9.05 and 3.031. To covariate control group (UC) are 10.76 and 1.690 respectively, mean and the initial scores of UK elementary school students on their standard deviation of experimental group I (UEA) are 11.63 mathematical skills, test of analysis of covariance was applie and 2.297 respectively and mean and standard deviation of and the results of univariate test are presented in table 4.

\begin{tabular}{l|cc|c|c|c}
\multicolumn{1}{r}{ Source of Variation } & Sum of Squares & df & Mean Square & $\boldsymbol{F}$ & Significance of $\boldsymbol{F}$ \\
\hline Covariates (pre-test) & 96.338 & 1 & 96.338 & 22.105 & $<0.001$ \\
\hline Main Effect (Treatment) & 57.523 & 2 & 28.761 & 6.600 & 0.002 \\
\hline Explained & 318.143 & 73 & 4.358 & & \\
\hline Residual & 9169.00 & 77 & & & \\
\hline Total & 500.312 & 76 & & & \\
\hline
\end{tabular}

Table 4: Effectiveness of Multimedia Packages vis a vis Mathematical Skills for UK Students, 2019, (Source: own calculation)

It is revealed from table 4 that $F$ value of 'Method' comes development of mathematical skills of elementary school out to be 6.600 and significant value $0.002<0.01$ which students of UK

is significant at 0.01 level of significance which shows the It can be inted that multimedia packages deved by existence of significant difference in mathematical skills using techniques of at and Vedic aphorisms have significant of UK elementary school students of Control group (UC), effect on the development of mathematical skills among experimental group I(UEA) and experimental group II(UEV) elementary school students of UK. The findings also reveal

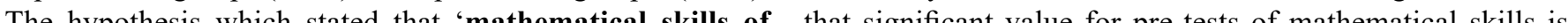
UK elementary school students will significantly improve $<0.01$ which means that the difference in Pre-test scores of with multimedia packages developed by using techniques mathematical skill test have significant effect on experiment of art and Vedic aphorisms' has been accepted. Therefore, manipulation. Therefore, it is obligatory to do the post hoc multimedia packages developed by using techniques of art analysis to find the actual difference between post-test of UC, and Vedic aphorisms have been found to be effective for UEA and UEV. Table 5 shows the post-hoc analysis.

\begin{tabular}{c|cc|c|c}
\hline Name of the Group & Name of the Group & Mean Difference & Std. Error & Significance value \\
\cline { 2 - 6 } UC & UEA & 0.967 & 0.556 & 0.090 \\
\hline \multirow{2}{*}{ UEA } & UEV & 1.186 & 0.621 & 0.060 \\
\cline { 2 - 5 } & UC & 0.967 & 0.566 & 0.090 \\
\hline \multirow{2}{*}{ UEV } & UEV & $2.153^{*}$ & 0.593 & 0.001 \\
\hline & UC & 1.186 & 0.621 & 0.060 \\
\hline
\end{tabular}

significant at 0.01 level of significance

Table 5: Pairwise Comparison- Dependent Variable: Post Test Scores of Mathematical Skills Test, 2018-2019, (source: own calculation)

Table 7, indicates that mean difference between control group Comparison of Mathematical Skills of India and (UC) and experimental group I (UEA) is 0.967, control UK students with Multimedia Packages using group (UC) and experimental group II (UEV) is 1.186 and Techniques of Art

experimental group I (UEA) and experimental group II (UEV) To compare mathematical skills of elementary school students is 2.153. The significant value of UC and UEA is $0.09>$ of India and UK with multimedia packages developed by 0.05 which is not significant at 0.05 level of significance, the using Techniques of Art, a pretest of mathematical skills significant value of UC and UEV is $0.060>0.05$ which is not was administered by the investigator on elementary students significant at 0.05 level of significance whereas the significant studying in schools of UK and India. Then, the students were value of UEA and UEV is $0.001<0.01$ which is significant at taught topics of elementary mathematics with multimedia 0.01 level of significance. packages using techniques of arts and followed by a post-test By comparing the means of UEA and UEV, it can be interpreted of mathematical skills. Scores of pre-test and post-test of both that multimedia packages developed by using techniques of the experimental groups were calculated and tabulated. The art are more effective in developing the mathematical skills descriptive statistic for experimental group (India) IEA and of UK elementary school students as compared to multimedia experimental group (UK) UEA has been presented in table 6 packages developed by using Vedic Aphorisms. and table 7 reveals the results of analysis of covariance.

\begin{tabular}{c|c|c|c} 
Name of the group & Mean & Std. Deviation & $\boldsymbol{N}$ \\
IEA & 9.72 & 2.851 & 25 \\
\hline UEA & 11.63 & 2.297 & 30 \\
\hline Total & 10.76 & 2.715 & 55 \\
\hline
\end{tabular}

(a) Comparison of Mathematical Skills of Indian \& UK students viz a viz Techniques of Art- Descriptive Statistics, 2019 (Source: own Calculation

Table 6 explains that the values of mean and standard deviation deviation of UEA 11.63 and 2.297 respectively. To covariate of IEA are 9.72 and 2.851 respectively, mean and standard the initial scores of Indian and UK elementary school students

\begin{tabular}{l|c|c|c|c|c}
\multicolumn{1}{c}{ Source of Variation } & Sum of Squares & df & Mean Square & $\boldsymbol{F}$ & Significance of $\boldsymbol{F}$ \\
\hline Covariates (pre-test) & 64.721 & 1 & 64.721 & 11.880 & 0.001 \\
\hline Main Effect (vis-à-vis Country) & 53.258 & 1 & 53.258 & 9.776 & 0.003 \\
\hline Explained & 283.286 & 52 & 5.448 & & \\
\hline Residual & 6770.000 & 55 & & & \\
\hline Total & 3.927 & 54 & & &
\end{tabular}

7: Mathematical Skills (India and UK) viz a viz Techniques of Art - ANCOVA results, 2019 (Source: own Calculation)

ERIES Journal

volume 13 issue 3

Frinted ISSN

1803-1617 2336-2375 
on their mathematical skills, test of analysis of covariance was applied and the results of univariate test are presented in table 7 , comes out to be 9.776 and sig. value is $0.003<0.01$ which is significant at 0.01 level of significance. It implies that there exists significant difference in mathematical skills of elementary school students of IEA and UEA. The hypothesis which stated that 'no significant difference in mathematical skills of Indian and UK elementary school students with multimedia packages developed by using techniques of

art' has been rejected. Therefore, it can be interpreted from an and UK elementary school students with multimedia ackages using techniques of art differs significantly.

9 also reveals that significant value for pre-tests of means the dif of IEA and UEA is $0.001<0.01$ which mathematical skills test) of IEA and UEA have significant effect on experiment manipulation. The post hoc analysis has been presented in table 8 .

\begin{tabular}{c|c|c|c|c} 
Name of the Group vis-à-vis Country & Name of the Group vis-à-vis Country & Mean Difference & Std. Error & Significance value \\
\hline IEA & UEA & $1.977^{*}$ & 0.632 & 0.003 \\
\hline UEA & IEA & $1.977^{*}$ & .632 & .003 \\
\hline
\end{tabular}

\section{* Significant at 0.01 level of significance}

\section{Table 8: Pairwise Comparison- Dependent Variable: Post Test Scores of Mathematical Skills Test, 2019, (source: own calculation)}

From table 8, it is observed that mean difference between students of India and UK with respect to multimedia IEA and UEA is 1.997. The significant value of IEA and packages of Vedic Aphorisms, a pretest of mathematical UEA is $0.003<0.01$ which is significant at 0.01 level of skills was administered by the investigator on elementary significance. By comparing the means of IEA and UEA, it students studying in schools of UK and India. After the can be construed that multimedia packages developed by pretest, students were taught the topics of elementary using techniques of art have improved the mathematical mathematics with multimedia packages developed using skills of UK elementary school students than to Indian elementary school students.

Cost of mathematical skills. Scores of pre-test and postComparison of Mathematical Skills with tabulated. The descriptive statistic for experimental group Multimedia Packages developed by using Vedic (India) IEA and experimental group (UK) UEA has been Aphorisms (India and UK)

To compare the mathematical skills of elementary school analysis of covariance.

\begin{tabular}{l|c|c|c}
\multicolumn{1}{c}{ Name of the group } & Mean & Std. Deviation & $N$ \\
\hline Indian Exp withV & 6.76 & 2.538 & 17 \\
\hline Uk Exp withV & 9.05 & 3.031 & 22 \\
\hline Total & 8.05 & 3.017 & 39 \\
\hline
\end{tabular}

Table 9: Descriptive Statistics of Mathematical Skills of Indian and UK Students viz a viz Vedic Aphorisms 2019 (Source: own Calculation)

From table 9 , it is clear that the values of mean of Indian and UK elementary school students on their and standard deviation of IEV are 6.76 and 2.538 mathematical skills, test of analysis of covariance was respectively, mean and standard deviation of UEV 9.05 applied and the results of univariate test are presented and 3.031 respectively. To covariate the initial scores in table 10 .

\begin{tabular}{l|r|r|r|r|c}
\multicolumn{1}{c|}{ Source of Variation } & Sum of Squares & df & Mean Square & $\boldsymbol{F}$ & Significance of $\boldsymbol{F}$ \\
\hline Covariates (pre-test) & 103.069 & 1 & 103.069 & 19.231 & 0.000 \\
\hline Main Effect (vis-a--vis Country) & 14.572 & 1 & 14.572 & 2.719 & 0.108 \\
\hline Explained & 192.945 & 36 & 5.360 & & \\
\hline Residual & 2874.000 & 39 & & & \\
\hline Total & 345.897 & 38 & & & \\
\hline
\end{tabular}

10: Mathematical Skills (India and UK) viz a viz Vedic Aphorisms- ANCOVA results, 2019 (Source: own Calculation)

Table 10 reveals that $F$ value against 'Country' comes skills of Indian and UK elementary school students out to be 2.719 and significant value is $0.108>0.05$, with multimedia packages developed by using Vedic which is not significant at 0.05 level of significance. Aphorisms has been accepted. Therefore, it can be It infers that there does not exist significant difference interpreted from the above findings that development in mathematical skills of elementary school students of mathematical skills of Indian and UK elementary of IEV and UEV. The hypothesis which stated that school students with multimedia packages using Vedic 'no significant difference will exist in mathematical Aphorisms does not differ significantly.
DISCUSSION

The multimedia packages developed by using techniques of art and Vedic aphorism have not revealed effectiveness for developing mathematical skills of elementary school students of India. According to the investigator, the reason may be that learning for the students of elements ar classes in India. students are already well accustomed with the tradition methods for developing basic skills in mathematics. Learning something new needs a lot of drill work especially in the subject of mathematics. Although the students were interested in solving the problems of mathematics in their post-test after learning through multimedia, combined with vedic aphorism and techniques of art, still, watching multimedia lessons only once would not have enhanced their mathematical skills and they need more time and practice to become fully acquainted with vedic aphorisms and art techniques for the development of their skills in the subject of mathematics. Due to this reason, the effectiveness of multimedia packages is not proved to be significant in case of elementary school students of India.

The multimedia packages developed by using techniques of art have been effective in developing mathematical skills among elementary school students of UK. During the research, investigator felt that most of the students specially in UK were very much interested in learning mathematics through art. They loved to do activities using colors and were attracted towards the multimedia integrated with techniques of art for learning
skills in mathematics. When these students were exposed to the multimedia lessons using art techniques, they quickly picked up and did well in their posttest of mathematical skills.

Using Vedic aphorisms in solving the mathematical problems, the researcher found that more time and practice was required in the case of students of key stage 3 in UK. Due to these reasons, the elementary school students of UK have shown significan improvement in the development of their mathematical skills with multimedia packages developed by using techniques of art, but not with multimedia packages developed by using techniques of Vedic aphorisms.

When Indian and UK elementary school students were compared for the development of mathematical skills using multimedia packages developed by using techniques of art and Vedic aphorisms, the review from researches have explored that students learn better from words and pictures as compared to words alone, because audio visual animations appear to be most effective while presenting concepts or information (Betrancourt, 2005). Putting words, written as well as spoken and pictures (static graphic images), animations and video make the brain process more in working memory (Sweller, 2005).

The results of the studies conducted by Luzón and Letón (2015 127) and Rabkin and Redmond (2006: 60) support the finding of the present study that suitable inclusion of an animatio effect in the materials of teaching and learning of mathematic skills can facilitate the cognitive processes that specialize in selecting information, building representation models, and making sense, thus promoting students' learning ability, and
use of arts has positive impact on the academic achievement use of arts has positive impact on the academic achievement
of the students. They also suggested that those students who

\section{ERIES Journal}

volume 13 issue 3 are struggling in this particular subject could benefit the most om art intervention. These results also support the finding he present study that the multimedia packages developed by ing techniques of art have been found to be more effective as a peris students studying in the schools of UK. The results are also supported by Tramonti (2017: 9279) that use of technology combining with art in teaching and learning of mathematics in the classrooms can provide students with digital tools which emphasize the interactivity of learning process, evaluation and construct of new knowledge by stimulating the creativity and understanding the complex relations of mathematics and reality in a better way. The content taught through multimedia helps to illustrate and explain complex concepts in the way that were previously inaccessible through the traditional teaching resources and pedagogies, hence quality of education can be improved using ICT tools. Mathematics taught by using smart class as an ICT tool enhances the retention of elementary school students in the subject of mathematics (Sharma, 2018:

CONCLUSIONS

There are number of ways in which multimedia can be defined. For the present study, multimedia has been defined as the delivery of instructional content in the subject of mathematics using audio, video, pictures and animations. packages were developed with techniques of art and Vedic aphorisms to find out whether multiple modes of visual and auditory information help the students to develop their basic kills in mathematics subject. Arts have the power to explore the paths of self-knowledge and expression of self and when thers are trained to use art in any form in their classrooms, the transformation of learning environment occurs.

The integration of art with multimedia to teach mathematics to elementary classes has proved to be effective in development of mathematical skills of UK students as evealed by the results of present study. However, in the case of thdian elementary school students, the development f mathematical skills with multimedia packages using entradictory cesuls. The post-hoc analysis of the present study exper sidents significantly improved with multimedia packages thest knowledge thestigator, no research study has been conducted on int and andic aphorisms for the development of mathematical skills of elementary school students of India and UK, although few studies in context to mullinedia, vedic mathematics and achievement art to teach and learn 作 Pedertion of the subject. Pedagogical methods need to be improved in India and UK 列 developed, entisms so that students skills in mathematics developed, enhances their overall achievement. $\begin{array}{rr}\text { Electronic ISSN } & \text { Printed ISSN } \\ \mathbf{1 8 0 3 - 1 6 1 7} & \mathbf{2 3 3 6 - 2 3 7 5}\end{array}$ 


\section{REFERENCES}

Ausubel, D. P. (1990) Education and Cognitive Processes: Psychological Guidance for the Teachers. Edotore, Milano:

Betrancourt, M. (2005) The Animation and Interactivity Principles in Multimedia Learning. New York: Cambridge University

Borko, H., Jacobs, J., Eiteljorg, E., and Pittman, M. E. (2008) 'Video as a Tool for Fostering Productive Discussions in Mathematic Vol. 24, No. 2, pp. 417-436. https:///doi.org/10.1016/j tate.2006.11.012

Brophy, J. E. (2004) Using Video in Teacher Education. Oxford UK: Elsevier.

Brown, M., Brown, P. and Bibby, T. (2008) 'I would rather die: Reasons given by 16 years old for not continuing Education, Vol. 10, No. 1, pp. 3-18. https://do org/10.1080/14794800801915814

Björklund, C. and Björkman, E. A. (2017) 'Approaches to teaching in thematic work: early childhood teachers' integration of mathematics and art', International Journal of Early Years Education, Vol. 25, No. 2, pp. 98-111. http://dx.doi.org/10.10 A. C. K. and Stavin,

Cheung, A. C. K. and Slavin, R. E. (2013) 'The effectiveness of achievement in K-12 classrooms: A meta-analysis', Educational Research Review, Vol. 9, pp. 88-113, http://dx doi org/10.1016/j.edurev.2013.01.001

Clark, L. (2012) 'Maths 'too hard for students and dons': Universities drop subject from science courses', Mail Online. 10 February, Available at: https://www.dailymail.co.uk/news article-2099022/Maths-hard-students-dons-Universities-dropsubject-science-courses.htm

Dani, S. G. (1993) 'Myth and reality: on 'Vedic Mathematics', Frontline, Vol. 10, No. 21, pp. $90-92$.

Fenyvesi, K. Koskimaa, R. and Lavicza, Z. (2015) 'Experientia Education of Mathematics: Art and Games for Digit Natives', Kasvatus ja aika, Vol. 9, №. 1, pp. 107-134

Flanagan, F. (2002) An Educational Enquiry into the use of Concep Mapping and Multimedia to Enhance the Understanding

Fowler, C. (1996) Strong arts, strong schools: The promising potential and shortsighted disregard of the arts in American

Ghazzawi, M.T. (2002) 'Designing an Instructional Software and Studying Its Effects and the Effect of the Motion Variable or Journal of Educational and Psychological Sciences, Vol 3, No. 4, pp. 14-51. http://dx.doi.org/10.12785/JEPS/030401

Harlin, R. and Brown, S. (2007) 'An arts-integrated approach for 3, pp. 172-174. https://dx.doi.org/10.1080/00094056.2007.105 $\underline{22905}$

Hillman, J. (2014) Mathematics after 16: the state of play challenges and ways ahead, Nuffield Foundation, [Online], Available: hhtps://www.nuffieldfoundation.org/sites/default
files/files/Mathematics_after_16___FINAL.pdf [9 Sep 2020].
Noyes, A. and Sealey, P. (2012) 'Investigating participation in https.//doi org/10.1080/02671520903288885

Pryor, C. R. and Bitter, G. G. (2008) 'Using multimedia to teach inservice teachers: Impacts on learning, application, and

Rabkin, N. and Redmond, R. (2006) 'The arts make a diffe Educational Leadership, Vol. 63, No. 5, pp. 60-64

Richard, D. (ed.) (2002) Critical Links: Learning in the Arts and Student Academic and Social
D.C.: Arts Education Partnership.

Seago N. (2015) 'Using Video as an Object of Inquiry for Mathematics Teaching and Learning', Advances in Research on Teaching, Vol. 10, pp. 259-286. http://dx.doi.org/10.1016 \$1479-3687(03)10010-7

Shadish, W. R., Cook, T. D. and Campbell, D. T. (2002) Experimental and qusi experimental designs for generalized casual inference. Boston: Houghton-Mifflin,

Sharma, H. (2018) 'Effectiveness of educomp smart classroom teaching on retention in mathematics at elementary level Development, Vol 3, No. 6, pp. 160-164. Advanced level mathematics: A study of student drop-out', 2668-2681. https://doi.org/10.1016/j.chb. 2008.03.007

Slavin, R. E. and Smith, D. (2009) 'Effect of sample sizes on effect size in systemic reviews in education', Educational 506. http://dx.doi.org/10.3102/0162373709352369

Slavin, R. and Madden, N. A. (2011) 'Measures inherent to treatments in program effectiveness reviews', Journal of Research on Educational Effectiveness, Vol. 4, No. 4, pp.

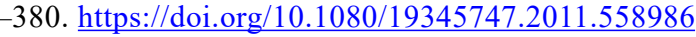
weller, J. (2005) Implications of cognitive load theory for Press.

Tramonti, M. (2017) 'Mathematics Education reinforced through innovative learning processes', EDULEARN17 Proceedings, pp.
edulearn.2017.0744

Tramonti, M. (2018) Tecthology and Art to Inprove Mathematics Learning, In Proceedings of INTED2018 Conference. Valencia, Spain, pp. 1492-1497. http://doi.org/10.21125/ inced.2018.0254 $1-12$.

Ig, D. H. and Cohen-Evron, N. (2000) 'Curriculum integration positions and practices in art education', Studies in Art Education,
Vol. 41, No. 3, pp. 285-275. https://dx.doi.org/10.2307/1320380 uzón, M. and Letón, E. (2015) 'Use of Animated Text to Improve the
Learning of Basic Mathematics', Computers \& Education, Vol. 88 , Learning of Basic Mathematics', Computers \& Education, Vol
pp. 119-128. https://doi.org/10.1016jj.compedu.2015.04.016

Maccini, P. and Gagnon, J. C. (2000) 'Best practices for teaching mathematics to secondary students with special needs', Focus on Exceptional Children, Vol. 32, No. 5, pp. 1-22. https://doi.
org/10.17161/foec.v32i5.6919

Maccini, P. and Gagnon, J. C. (2006) 'Mathematics instructional practices and assessment accommodations by secondary special and gener $217-234$.

Malik, S. and Aggarwal, A. (2012) 'Use of Multimedia as a New Educational Technology Tool-A Study', International Journal of http://dx.doi.org/10.7763/IJIET.2012.V2.181

Mayer, R.E. (2012) Multimedia Learning. Cambridge: $2^{\text {nd }}$ edition, Cambridge University Press. https://doi.org/10.1017/ CBO9780511811678

Mayer, R.E. and Johnson, C.I. (2008) 'Revising the redundancy principle in multimedia learning, Journal of Educational Psychology, Vol. 100, No. 2, pp. 380-386. https://doi.org/10.1037/00220663.100 .2 .380

Melnick, S. A., Witmer, J. T. and Strickland, M. J. (2011) 'Cognition and student learning through the arts', Arts Education Policy Review, Vol. 112, No. 3, pp. 154-162. https://doi.org/10.1080/10 632913.2011.566100

Prom Rest That Educational Psychology, Vol. 96, No. 1, pp. 165-173. hitps://doi. org/10.1037/0022-0663.96.1.165

Moreno, R. and Mayer, R. E. (2005) 'Role of Guidance, Reflection, and Interactivity in an Agent-Based Multimedia Game', Journal of org/10.1037/0022-0663.97.1.117

Moreno, R. and Valdez, A. (2007) 'Immediate and delayed effects of using a classroom case exemplar in teacher education: The role of presentation format', Journal of Educational Psychology, Vol. 99, No. 1, pp. 194-206. https://doi.org/10.1037/0022-0663.99.1.194 